\title{
Comparative Review of Brushless PMAC and PMDC Motor Drives
}

\author{
Rajesh M. Pindoriya, Graduate Student Member, IEEE \\ Indian Institute of Technology Mandi, Himachal Pradesh, India \\ rajeshpindoriya@gmail.com
}

\begin{abstract}
This paper presents a state of the art on brushless Permanent Magnet Alternative Current (PMAC) and Permanent Magnet Direct Current (PMDC) motor drives. The brushless PMAC and PMDC motor drives are the latest choices of researchers due to their high efficiency, silent operation, compact size, high reliability, and low maintenance requirements. These motors are preferred for numerous applications. An in-depth analysis of PMAC and PMDC motor drives have been discussed. The Permanent Magnets (PMs) motor drives can be classified into two categories, first is PMAC motor drives, i.e. PMSM and the second one is PMDC motor drives, i.e. BLDC motors. There has been a long misunderstanding between the two ways of driving and controlling a motor with no windings on the rotor but only PMs. In this paper given a comprehensive analysis of both motor drives. So, beginner of the research scholars are easily able to understand about brushless PMAC and PMDC motor drives.
\end{abstract}

Keywords- Brushless Direct Current (BLDC) motor drives, Permanent Magnets (PMs), Permanent Magnet Alternative Current (PMAC) motors, Permanent Magnet Direct Current (PMDC) motors, and Permanent Magnet Synchronous Motor (PMSM) drives.

\section{INTRODUCTION}

Electric motor drives are the most famous machines in regular day to day existence and their number of types increments with improvements in designing, science, and innovation. Electric motor drives are utilized in a wide power range from Ws to GWs. Over the most recent three decades, numerous new electric motor drives have been created and a few are in cutting edge model stage incorporating motors with superconducting field excitations [1]. The advancement of electric motor drives in the next few years will generally be animated by hardware, personal computer, domestic, industrial applications, and transportation frameworks (air, ocean, and land) [2], [3].

Broadly electric motor drives can be divided into two categories i.e. Alternative Current (AC) and Direct Current (DC) motor drives. Earlier DC drives were popular and were mostly used due to the advantages of easy speed control with good efficiency in comparison to AC drives. But with the advancement in power semiconductor converters and fast computing/processing facilities (such as digital signal processing), it is readily possible to control the AC drives that will give comparable performance to that of the DC drives [4]. AC drives utilizing control techniques such as Field Oriented Control (FOC) [5] and Direct Torque Control (DTC) are now gradually replacing DC drives in highperformance applications [6].

The main advantages of cage Induction Motor (IM) drives are their simple construction, low price, less maintenance, no commutator or slip-rings, and low sound power level as compared to other electric drives [7]. The drawbacks are their small air-gap, poor performance at low speeds, torque proportional to voltage squared, sensitivity to voltage drop, and lower efficiency and power factor than those of synchronous machines [3]. With the increasing performance of magnet material and decreasing cost, Permanent Magnet Synchronous Motor (PMSM) drives become more and more important for practical use in various applications. Hence, PMSM became the ideal choice for electric drives.

As of now, different kinds of AC drives utilizing, for example, IM, PMSM, Switched Reluctance Motor (SRM), etc., are broadly utilized in modern applications. Among the AC electric motor drives, PMSM drives frameworks have been utilized increasingly more in numerous industrial and domestic applications, e.g., electric and hybrid electric vehicles, and Wind Energy Conversion Systems (WECSs) [8], because of their unmistakable points of high power density, wide constant power region, high efficiency, etc. With the nonstop decrease in the expense of Permanent Magnets (PMs) materials and the advancement of control methods, PMSM drives have more striking and modest. A comparison of AC IM, DC, and PMs motor drives are given in Table 1 .

TABLE I. COMPARISION OF ELECTRIC MOTOR DRIVES [3], [4]

\begin{tabular}{|c|c|c|}
\hline AC IM drives & DC motor drives & PM motor drives \\
\hline $\begin{array}{l}\text { The speed-torque } \\
\text { characteristic is non- } \\
\text { linear }\end{array}$ & $\begin{array}{l}\text { The speed-torque } \\
\text { characteristic is } \\
\text { moderately flat }\end{array}$ & $\begin{array}{l}\text { The speed-torque } \\
\text { characteristic is flat }\end{array}$ \\
\hline $\begin{array}{l}\text { The output } \\
\text { power/frame size is } \\
\text { moderate. Because } \\
\text { both stator and rotor } \\
\text { have winding }\end{array}$ & $\begin{array}{l}\text { The output } \\
\text { power/frame size is } \\
\text { moderate. Because } \\
\text { both stator and rotor } \\
\text { have winding }\end{array}$ & $\begin{array}{l}\text { The output } \\
\text { power/frame size is } \\
\text { high. Because it has } \\
\text { PM on the rotor, the } \\
\text { smaller size can be } \\
\text { achieved for a given } \\
\text { output power }\end{array}$ \\
\hline $\begin{array}{l}\text { The rotor inertia is } \\
\text { high }\end{array}$ & $\begin{array}{l}\text { The rotor inertia is } \\
\text { high }\end{array}$ & $\begin{array}{l}\text { The rotor inertia is } \\
\text { low }\end{array}$ \\
\hline $\begin{array}{l}\text { The starting current is } \\
\text { approximately up to } 7 \\
\text { times the rated }\end{array}$ & $\begin{array}{l}\text { The starting current } \\
\text { is rated }\end{array}$ & $\begin{array}{l}\text { The starting current } \\
\text { is rated }\end{array}$ \\
\hline $\begin{array}{l}\text { No controller is } \\
\text { required for fixed } \\
\text { speed. The controller is } \\
\text { required only if } \\
\text { variable speed is } \\
\text { required }\end{array}$ & $\begin{array}{l}\text { No controller is } \\
\text { required for fixed } \\
\text { speed. The controller } \\
\text { is required only if } \\
\text { variable speed is } \\
\text { required }\end{array}$ & $\begin{array}{l}\text { A controller is } \\
\text { always required to } \\
\text { keep the motor } \\
\text { running. } \\
\text { controller can be } \\
\text { used for a variable } \\
\text { speed controller }\end{array}$ \\
\hline $\begin{array}{l}415 \text { volt 4-pole flange } \\
\text { mounted cast iron } \\
\text { motor, } 1440 \mathrm{rpm} \text {, } \\
\text { weight: } 160 \mathrm{~kg}, 50 \mathrm{~Hz} \text {, } \\
\text { insulation }=\text { F-class, } \\
\text { efficiency }=80-87 \% \\
\text { (in practical). }\end{array}$ & & $\begin{array}{l}\text { Model: HPM-10 kW, } \\
\text { Voltage: } 48 \mathrm{~V}, \\
\text { Efficiency: } \\
\text { Speed: } 4000 \quad \mathrm{rpm} \% \\
\text { weight: } 17 \mathrm{~kg} . \\
\text { Price: } 1,27,818 \text { INR }\end{array}$ \\
\hline $\begin{array}{l}\text { Price }=31,000 \text { INR } \\
\text { (Faridabad Control } \\
\text { Electrical Pvt. Ltd.) }\end{array}$ & & $\begin{array}{lr}\text { (Golden } & \text { Motor } \\
\text { Technology } & \text { Co., } \\
\text { Ltd.) } & \end{array}$ \\
\hline
\end{tabular}


This paper discussed the in-depth analysis of PMAC and PMDC motor drives. The effect of the shape of the stator winding and magnets on the rotor of the PMAC and PMDC motor drives presented in this paper. Comparison of AC IM, DC motor, and PM motor drives technology discussed in detail.

The organization of this paper is as follows. Section II presents a state of the art of PMAC and PMDC motor drives. Control mechanism of PMAC and PMDC motor drives presented in section III. Acoustic noise and vibration in PMAC and PMDC motor drives is explained in section IV. Condition monitoring and fault diagnosis discussed in section $\mathrm{V}$. The research scope is presented in section VI.

\section{STATE-OF-THE-ART OF PMAC AND PMDC MOTOR DRIVES}

The PM AC and DC motor drives are kind of synchronous motor drives in which PMs are used as a rotor to create field poles. No field winding is wound on the rotor. The basic construction of PM AC and DC motors is the same as that of synchronous motors. The only difference lies with the rotor. Field poles are created by using PM. These PMs are made up of high permeability and high coercivity materials like Samarium-Cobalt (SmCo) and Neodymium-Iron-Boron (NdFeB) are mostly used due to its ease of availability and cost-effectiveness. These PMs are mounted on the rotor core.

The PMs motor drives can be classified into two categories, first is PMAC motor drives, i.e. PMSM and the second one is PMDC motor drives, i.e. BLDC motors. There has been a long misunderstanding between the two ways of driving and controlling a motor with no windings on the rotor but only PM. When they first motor of this type was developed some 50 years ago it was called a brushless DC motor because it evolved from a DC motor which had a commutator and brushes. The principle method for controlling this motor was using a DC power supply and transistors to switch the voltages across any to lead wires or any two phases so that the current flowed according to Ohm's law in two phases at a time. Commutation or switching the voltage between other two-phase connections was known as a six-step or trapezoid drive [9].

Some 20 years after the introduction of the brushless DC motor control engineers began to control IM in such a way to improve their performance substantially as compared to two operations off the grid. Involved using transformation theory such as Parks and converting the three-phase current vectors into two current vectors one for magnetizing current and the other for torque producing current. With this control technique and the IM is driven by a three-phase inverter that could perform very similar to a brushless servo motor. It was not long afterward when the same control method was used to control the brushless DC motor with magnets on the rotors. The big difference now is that the speed of the DC motor is no longer control by voltage but controlled by frequency just like the AC IM is controlled with the same type of flux vector drive [10].

The three-phase stator winding configuration of PMAC and PMDC motor drives are shown in Fig. 1 and Fig. 2 [11]. The stator winding of the PMAC motor is distributed and concentrated in PMDC motor drives. Based on the winding configuration and control method, PM motors are classified into two categories. First is sinusoidal back Electro-Magnetic Force (EMF) PMAC motor and the second is trapezoidal back EMF PMDC motor drives. The three-phase stator distributed winding of the PMSM drive is shown in Fig. 1 (a). The three-phase stator concentrated winding of a BLDC motor is shown in Fig. 1 (b). The pictorial view of the threephase stator winding of PMAC and PMDC motor drives are shown in Fig. 2 (a) and Fig. 2 (b), respectively. A comparison between PMAC and PMDC motor drives are given in Table 2.

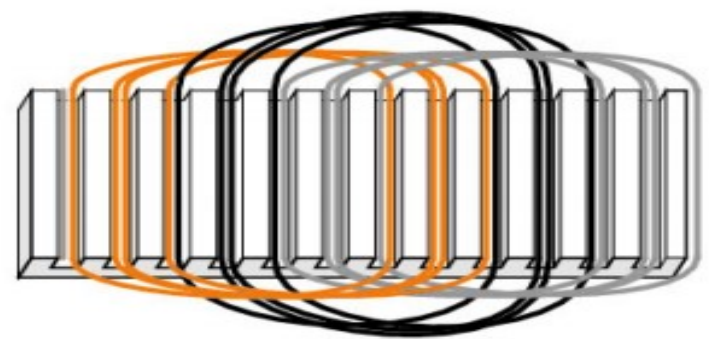

(a)

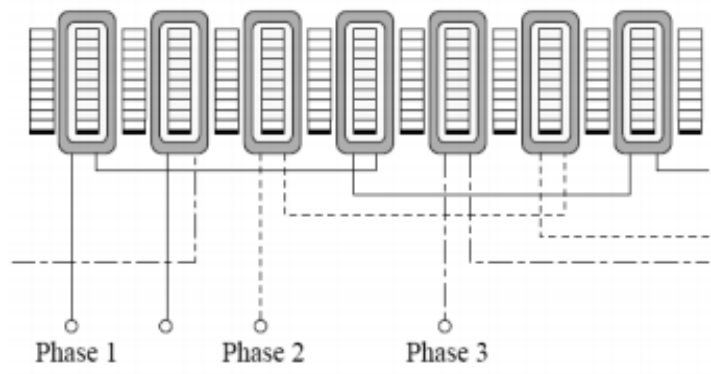

(b)

Fig. 1. The three-phase stator winding of permanent magnet motors: (a) Distribution winding and (b) contracted to wind [11].

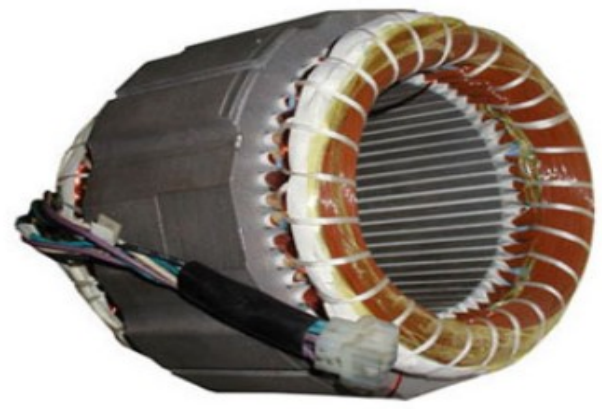

(a)

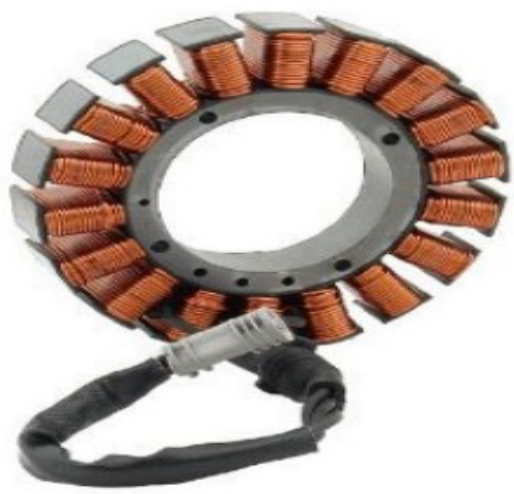

(b)

Fig. 2. Pictorial view of a stator of PM motors: (a) distributed winding (PMSM) and (b) concentrated winding (BLDC) [11]. 
TABLE II. COMPARISON OF PMSM AND BLDC MOTOR DRIVES

\begin{tabular}{|c|c|}
\hline PMAC motor drives & PMDC motor drives \\
\hline Fed with AC & Fed with DC \\
\hline $\begin{array}{l}\text { Sinusoidal flux density (driven by } \\
\text { magnetic design) }\end{array}$ & $\begin{array}{l}\text { Square flux density (driven by } \\
\text { magnetic design) }\end{array}$ \\
\hline $\begin{array}{l}\text { Back EMF is sinusoidal (driven by } \\
\text { winding and magnets design) }\end{array}$ & $\begin{array}{l}\text { Back EMF is trapezoidal } \\
\text { (driven by winding and magnets } \\
\text { design) }\end{array}$ \\
\hline $\begin{array}{l}\text { Current is sinusoidal (driven by } \\
\text { the controller, which makes the } \\
\text { controller more complex and } \\
\text { costlier) }\end{array}$ & $\begin{array}{l}\text { Current is trapezoidal (driven by } \\
\text { the controller, which makes the } \\
\text { controller easier and cheaper) }\end{array}$ \\
\hline $\begin{array}{l}\text { For equal resistive losses, power } \\
\text { density is less }\end{array}$ & $\begin{array}{l}\text { For equal resistive losses, power } \\
\text { density is } 15.4 \% \text { higher than } \\
\text { PMAC }\end{array}$ \\
\hline $\begin{array}{l}\text { The conduction and switching } \\
\text { losses are higher because of three } \\
\text { transistors in inverter conduct }\end{array}$ & $\begin{array}{l}\text { The conduction and switching } \\
\text { losses are smaller because of } \\
\text { only two transistors in the } \\
\text { inverter conduct }\end{array}$ \\
\hline $\begin{array}{l}\text { Torque ripple due to the } \\
\text { commutation of currents is low }\end{array}$ & $\begin{array}{l}\text { Torque ripple due to the } \\
\text { commutation of currents is high. }\end{array}$ \\
\hline $\begin{array}{l}\text { The coils of distributed winding } \\
\text { are not Co-axial. They are rather } \\
\text { distributed in various slots along } \\
\text { the air-gap periphery }\end{array}$ & $\begin{array}{l}\text { The coils of the concentrated } \\
\text { winding are co-axial. This } \\
\text { means, all the winding has the } \\
\text { same magnetic axis }\end{array}$ \\
\hline $\begin{array}{l}\text { The emf induced in such winding } \\
\text { is independent of pitch and } \\
\text { distribution factor } \\
\qquad E=4.44 \times N_{\mathrm{ph}} \times f \times \phi\end{array}$ & $\begin{array}{l}\text { The emf induced in the } \\
\text { distributed winding is } \\
\text { dependent on the value of pitch } \\
\text { factor " } K_{\mathrm{p}} \text { " and distribution } \\
\text { factor " } K_{\mathrm{d}} \text { " } \\
E=4.44 \times N_{\mathrm{ph}} \times f \times \phi \times K_{\mathrm{p}} \times K_{\mathrm{d}}\end{array}$ \\
\hline $\begin{array}{l}\text { The torque equation is given by } \\
T_{e}=\left(\frac{3}{2}\right)\left(\frac{P}{2}\right)\left[\left(\lambda_{f}\right)-\left(L_{d}-\right.\right. \\
\left.\left.L_{q}\right) I_{d}\right] I_{q}\end{array}$ & $\begin{array}{l}\text { The torque equation is given by } \\
T_{e}=\frac{\left[\left(E_{a} I_{a}\right)+\left(E_{b} I_{b}\right)+\left(E_{c} I_{c}\right)\right]}{\omega_{m}} \\
\text { where, } \\
E_{a}=F_{a}\left(\theta_{r}\right) \times \lambda_{f} \times \omega_{m} \\
E_{b}=F_{b}\left(\theta_{r}\right) \times \lambda_{f} \times \omega_{m} \\
E_{c}=F_{c}\left(\theta_{r}\right) \times \lambda_{f} \times \omega_{m}\end{array}$ \\
\hline
\end{tabular}

\section{A. High-Performance PMAC and PMDC Motor Drives}

Power electronic converter fed AC/DC drives have their place with the cutting-edge industry and are one of the primary variables for efficiency and energy-saving development [3]. The fundamental piece of all the created electric energy is utilized to feed electric motor drives and the transformation of electrical power into mechanical power includes motors extending from under one $\mathrm{W}$ up to $\mathrm{GW}$. The present-day drive ought to be high-performance characteristics which are as following [10]:

14 Maximum energy conversion efficiency,

15 Fast mistake removal when the control and additionally unsettling influence signals are being changed,

16 Reliable, user-friendly operation

17 Wide range tuning of electromagnetic torque, rotor speed, acceleration, and linear position

18 Maximum usage of motor power under diminished voltage, current, etc.

If any electric drive has the above characteristic, then it is a called high-performance electric drive. The two fundamental divisions of modern technology first are Digital Signal Processing (DSP) and second is semi-conductor power electronics converters, which have opened the best approach to change ordinary electrical motors to special electrical motors [4]. The special electrical motors mean brushless permanent magnet variable speed synchronous motors, switched reluctance motors, and stepper motors.

\section{B. Limitations of High-Performance PMAC and PMDC Motor Drives}

The PMAC and PMDC motor drives cannot compete with conventional motors in large range or even in the medium power range. This is because a PMSM and BLDC motor drives cannot match the performance of conventional threephase motor IM when driven as Voltage Frequency Drive (VFD) control [10]. Large motors rated for hundreds to thousands of HP (e.g., traction, industries, power plant, steel plants, etc.) are almost invariably three-phase IM or synchronous machine. No doubt, PMSM, and BLDC motors are quite successful in a small motor bracket where it replaces single-phase capacitors motors, shaded pole motor, and series motor used in mixtures. The cost and reliability of the electronic controller often become a limitation when PMSM and BLDC motors have to replace established motor like capacitor rum motor. This is especially true of fan compressors and pumps whose load characteristics (torque vs speed) match the torque characteristics (motor torque vs speed) of IM [10].

All motors with magnets on the rotor and windings in the stator are brushless motors. They are named BLDC if driven with a trap 6 step drive. They are named PMAC if driven with a sine drive. So yes, a BLDC motor can be driven with a three-phase sine drive but then you no longer call it a BLDC motor but rather a PMAC motor. The motor does not change, or no design changes are required in the BLDC motor to drive it either way. For sure if you know ahead of time how it will be driven you can optimize the motor system performance by certain design optimization of the motor geometry. For example, tapered air gaps, magnet arc length, parallel vs radial magnetization, number of magnets per pole, and placement as spokes or as we are all optional.

Fig. 3 shows the torque-speed curve of PMSM used in EVs. Different ranges of speed and torque variation are given as constant torque, constant power, and high-speed region. During the constant torque region of the PMSM, rated speed is not reached, and constant torque is exerted. When speed meets the rated motor speed, torque reduces proportionally which leads to constant output power. When the speed increases further, the constant power section ends. Furthermore, motor torque reduces proportionally to the square of the speed.

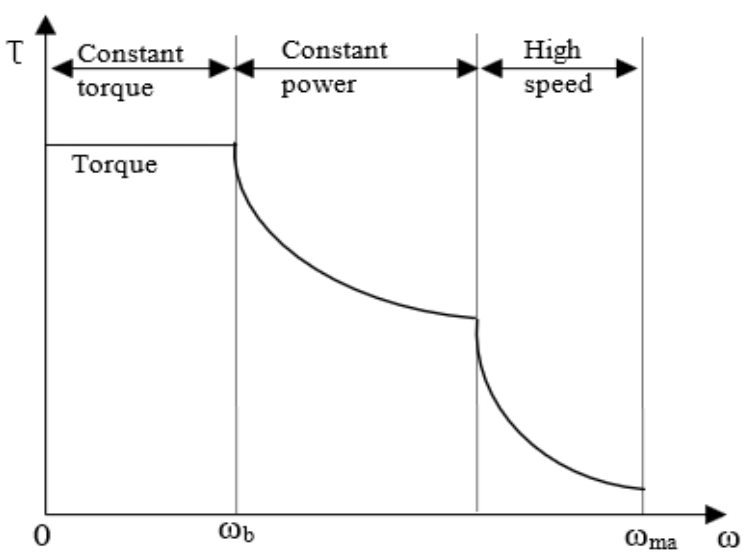

Fig. 3. Torque speed characteristics of PMSM. 


\section{General comments:}

The general comments are given below, which are useful to design and choose the drives for various applications.

1-Radial magnetization of rare earth magnets is near impossible to purchase unless very expensive tooling is purchased. Most rare earth magnets are parallel magnetized. (The exceptions are ceramic magnets or molded magnets)

2- Due to eddy current heating losses in the magnets and rotor cores the rotor core should be laminated like the stator and the magnet poles should be segmented into multiple magnets glued together to mitigate eddy current losses.

3- By far the lowest cost magnet configuration is in a slab form with no grinding. (Perfectly rectangular)

4-Magnet retainment against centrifugal forces is critical and must be accommodated for motor endurance.

5- Concentrated windings over single teeth result in the shortest end turns which is very important. Only certain combinations of pole numbers to slot numbers will result in balanced concentrated designs.

6-For BLDC motors (any motor with magnets on or in the rotor and windings in the stator) always choose the max number of poles that the drive can electronically commutate. (This results in the highest torque and power density.)

In general, the most broadly utilized PMSM has an outer stator with conductors and an inner rotor with PM. As per the rotor structures, the PMSM with sinusoidal back EMF can be comprehensively described into two significant classes: Surface-mounted (SPMSM), and Interior (IPMSM) [3]. The rotor comprises of PM. Materials with high coercive power are utilized as PM. As indicated by the rotor structure, synchronous motors are divided into two types are as following [3], [4]:

- Electric motors with salient pole rotor.

- Electric motors with a non-salient pole rotor.

An electric motor with a non-salient pole rotor has an equally direct and quadrature inductance $\left(L_{\mathrm{d}}=L_{\mathrm{q}}\right)$, while in salient pole rotor the quadrature inductance is not equal to the direct $L_{\mathrm{q}} \neq L_{\mathrm{d}}$. The various type of PM rotors is shown in Fig. 4 [9]. The cross-area of a commonplace surface-mounted PMSM is shown in Fig. 4 (a). Since the PM is mounted on the outside of the rotor center, the SPMSM has a uniform effectively air gap. This property makes the simultaneous inductances indirect $(d)$ and quadrature $(q)$ axis to be equal. Thus, the SPMSM just delivers an attractive electromagnetic torque. The surface-mounted rotor setup is straightforward enough for assembling and gathering. But the PM is presented straightforwardly to the armature reaction field and at the danger of demagnetization. Because of the surfacemounted rotor structure, the rotating speed ought to be restricted to keep the $\mathrm{PM}$ at the rotor surface against the impact of the centrifugal force [3], [4].

A common cross-section area of an IPMSM is shown in Fig. 4 (c), where the magnets are covered and adequately protected in the rotor iron, which essentially reduces the danger of demagnetization of the PM during the fluxweakening operation. Because of the rotor saliency, the $d-q$ axis inductances are different [3]. Both the magnetic torque and the reluctance torque contribute to the total torque produced by the IPMSM. Therefore, IPMSM is more valid for traction applications in electric-drive vehicle frameworks, which require flux weakening operation and high output torque [4].

The PMSM can be extensively classified dependent on the direction of field flux as follows [3]:

1. Radial field: The flux direction is along the radius of the machine.

2. Axial field: The flux direction is parallel to the rotor shaft.

The radial field PM electric motors are normal while the axial field electric motors are coming into prominence in a small number of applications because of their more power density and acceleration capacity than its counterpart.

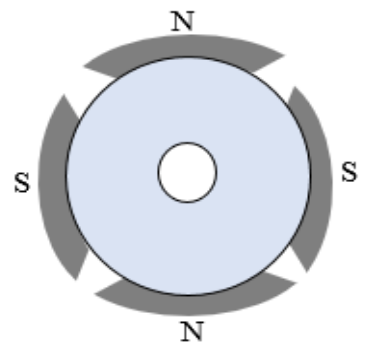

(a)

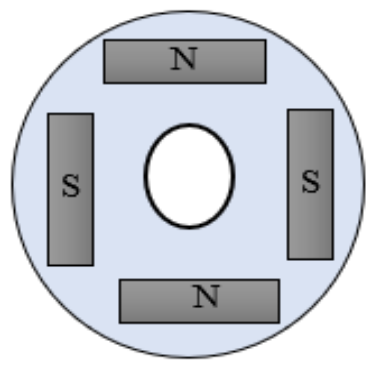

(c)

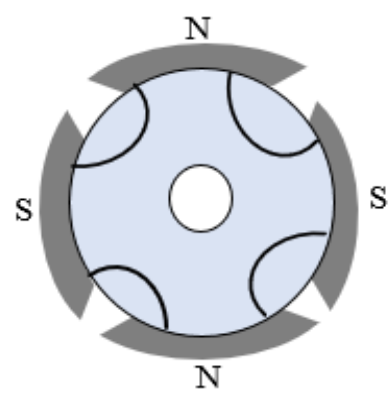

(e)

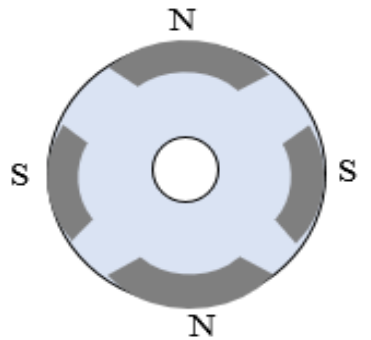

(b)

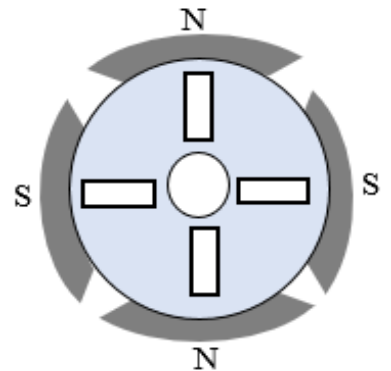

(d)

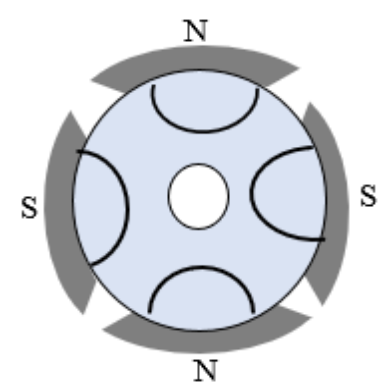

(f)
Fig. 4. The cross-sections the permanent magnet rotors with a different ratio of $L_{\mathrm{d}} / L_{\mathrm{q}}:$ (a) $L_{\mathrm{d}}=L_{\mathrm{q}}$, (b) $L_{\mathrm{d}}<L \mathrm{q}$, (c) $L_{\mathrm{d}}<L \mathrm{q}$, (d) $L_{\mathrm{d}}>L_{\mathrm{q}}$, (e) $L_{\mathrm{d}}>L_{\mathrm{q}}$, and (f) $L_{\mathrm{d}}$ $<L_{\mathrm{q}}$.

\section{CONTROL MECHNISM OF PMAC AND PMDC MOTOR DRIVES}

Since PMSM drives are synchronous motors, the exact torque can be created in these motors when the AC excitation frequency is synchronized with the rotor frequency. Hence, the essential condition in the control structure of PMSM is the affirmation of the exact synchronization of the motor's excitation with the rotor frequency [4]. The immediate way to deal with accomplish this requirement is the non-stop measurement of the total rotor position and, the excitation of the motors as needs be as shown in Fig. 5. This concept is 
also known as self-synchronization and it guarantees that the PMSM does not leave synchronization during operation [1]. The PMSM drives structure with speed and torque controller is shown in Fig. 5. The torque production of PMSM is related to the stator currents and the torque control incorporates the stator current control requiring stator current feedback to the torque control as shown in Fig. 5. the angular rotor position information is also essential to control the torque as well as the speed of the PMSM drives [3]. the vector control method implemented for the control of speed and current of the PMSM drives. The outer loop and inner loop are for the controlling of the speed and current of PMSM drives, respectively.

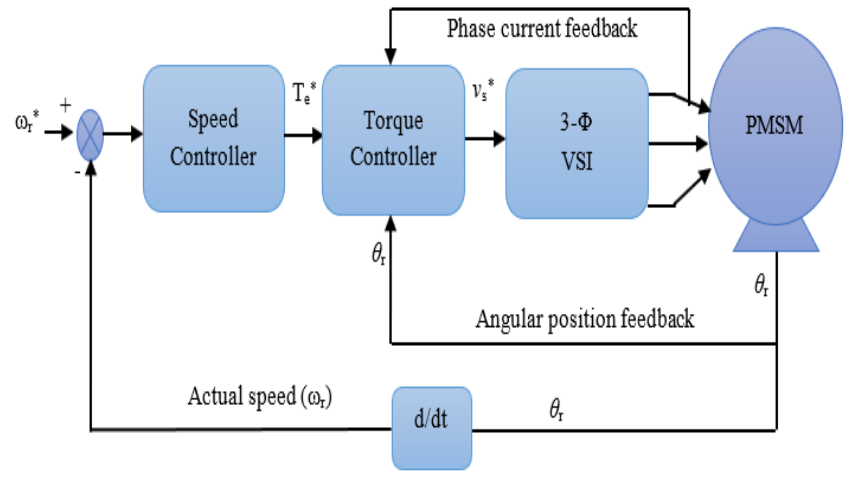

Fig. 5. Schematic layout of speed and torque control of PMSM drives.

Due to several disadvantages of sensor-based PMSM drive, many approaches are done to sensorless based PMSM drive. Disadvantages of sensor-based PMSM drive are as following [3-6]:
a. It reduces reliability.
b. Increase in weight.
c. Increases the complexity of drive.
d. Increases cost and size.

The rotor position information is mandatory to operate the PMSM drive. Normally rotor position information sense by hall effect, encoder, and proximately sensors. But nowadays industry and researchers have shifted from sensor to sensorless control of PMSM drive. Which provides advantages compare to sensor-based PMSM drive. The advantage of sensorless PMSM drives is as following [5], [6].

I. The drive is compact,

II. Less maintenance required,

III. Increases the mechanical robustness and

IV. The inertia of the overall system is not increased.

So, for sensorless operation of PMSM drive, many methods have been reported in the literature [6], [15], [16]. The block diagram of the rotor position sensorless operation of the PMSM drive is shown in Fig. 6. Here rotor position sensors are not there. So, the rotor position of the PMSM drive is estimated using stator voltage, current, and flux quantity of PMSM drive. In PMSM drive, the rotor position can be determined by flux linkage sensing [17], position dependence of inductances [18], current slope detection [19], zerocrossing back EMF, state observer-based [20], etc.
T. Muller et al. [17] presents a flux linkage sensing method to estimate the rotor and speed position of the PMSM drive. This method is dependent on the motor phase voltage equation. The flux linkages are a function of rotor position and current, therefore, the flux linkage in each phase can be estimated by continuously integrating voltage by subtracting the voltage drop due to resistance from phase voltage. An open-loop error can be reduced by replacing the pure integrator with a low pass filter. Practically we cannot measure phase voltages directly in most of the electrical machines, because of issues related to isolation; therefore, the applied voltage can be estimated by the DC supply voltage of the converter. The flux estimation method suffers at zero speed because the back EMF is zero.

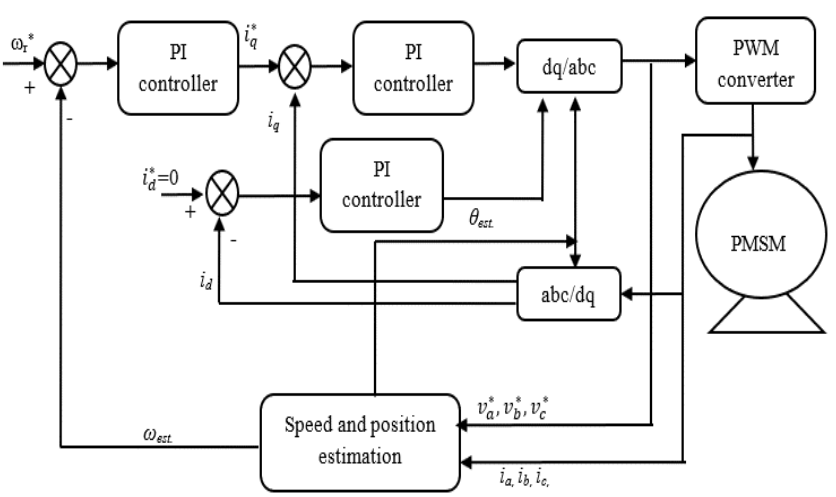

Fig. 6. Block diagram of rotor position sensorless operation of PMSM drive.

The rotor and speed position estimation methods can be classified into three major categories which are shown in Fig. 7 [21].

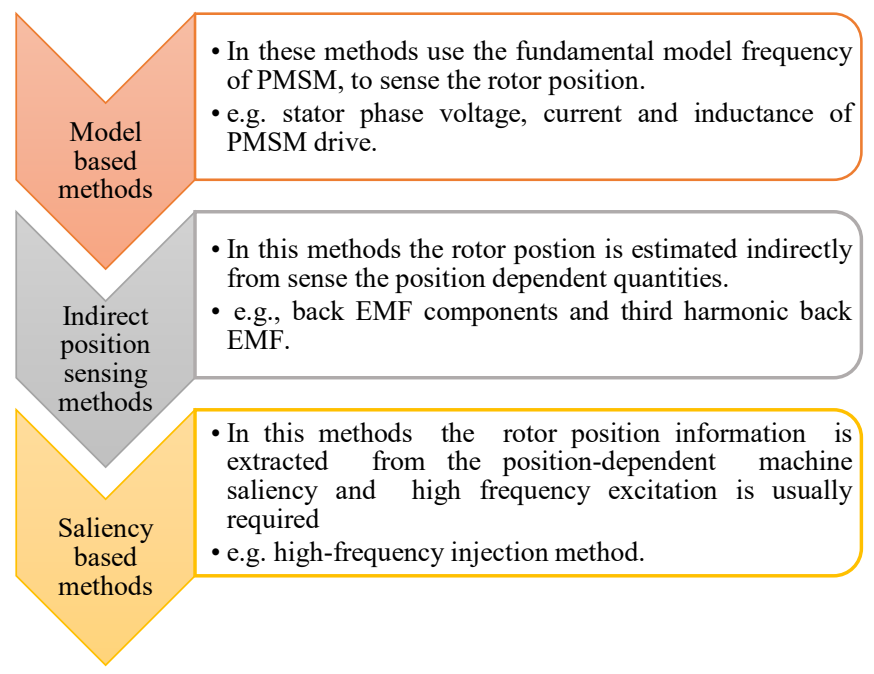

Fig. 7. Illustration of three major categories of methods to obtain rotor position information without using position sensors.

The PMAC and PMDC motor drives require a control system, for example, a variable frequency drive or a servo drive. There are a large number of control techniques implemented in control systems. The famous control strategies for PMAC and PMDC motor drives are given in Table III. 
TABLE III. FAMOUS CONTROL TECHNIQUES FOR PMAC AND PMDC MOTOR DRIVES

\begin{tabular}{|c|c|c|c|c|c|}
\hline \multicolumn{4}{|c|}{ Control } & Advantages & Disadvantages \\
\hline \multirow{4}{*}{$\sum_{0}^{\circlearrowright}$} & \multicolumn{3}{|c|}{ Scalar } & $\begin{array}{l}\text { Simple } \quad \text { control } \\
\text { scheme }\end{array}$ & $\begin{array}{l}\text { Control is not } \\
\text { optimal, not suitable } \\
\text { for tasks where the } \\
\text { variable load, loss of } \\
\text { control is possible }\end{array}$ \\
\hline & \multirow{3}{*}{$\frac{\grave{0}}{\stackrel{0}{0}}$} & & $\begin{array}{l}\text { With } \\
\text { position } \\
\text { sensor }\end{array}$ & $\begin{array}{l}\text { Smooth and precise } \\
\text { setting of the rotor } \\
\text { position and motor } \\
\text { rotation speed, large } \\
\text { control range }\end{array}$ & $\begin{array}{l}\text { Requires rotor } \\
\text { position sensor and } \\
\text { powerful } \\
\text { microcontroller } \\
\text { inside the control } \\
\text { system }\end{array}$ \\
\hline & & ঠৃ & $\begin{array}{l}\text { Without } \\
\text { a rotor } \\
\text { position } \\
\text { sensor }\end{array}$ & $\begin{array}{l}\text { No rotor position } \\
\text { sensor is required. } \\
\text { Smooth and precise } \\
\text { setting of the rotor } \\
\text { position and motor } \\
\text { rotation speed, large } \\
\text { control range, but } \\
\text { less than with } \\
\text { position sensor }\end{array}$ & $\begin{array}{l}\text { Sensorless field- } \\
\text { oriented control over } \\
\text { full speed ranges } \\
\text { possible only for } \\
\text { PMSM with salient } \\
\text { pole rotor, a } \\
\text { powerful control } \\
\text { system is required }\end{array}$ \\
\hline & & & DTC & $\begin{array}{l}\begin{array}{l}\text { A simple } \\
\text { circuit, }\end{array} \\
\text { dynamic } \\
\text { performance, wide } \\
\text { control range, no } \\
\text { rotor position sensor } \\
\text { required }\end{array}$ & $\begin{array}{l}\text { High torque and } \\
\text { current ripple }\end{array}$ \\
\hline \multirow{3}{*}{$\sum_{2}^{\circlearrowright}$} & \multicolumn{3}{|c|}{ Open-loop } & $\begin{array}{l}\text { Simple control } \\
\text { scheme }\end{array}$ & $\begin{array}{l}\text { Control is not } \\
\text { optimal, not suitable } \\
\text { for tasks where the } \\
\text { variable load, loss of } \\
\text { control is possible }\end{array}$ \\
\hline & \multirow[t]{2}{*}{$\begin{array}{l}\frac{0}{8} \\
0 \\
\frac{0}{0} \\
\frac{0}{0} \\
\frac{0}{U}\end{array}$} & & $\begin{array}{l}\text { h position } \\
\text { sensor }\end{array}$ & $\begin{array}{l}\text { Simple } \quad \text { control } \\
\text { scheme }\end{array}$ & $\begin{array}{l}\text { Hall sensors are } \\
\text { required. There are } \\
\text { torque ripples. It is } \\
\text { intended for control } \\
\text { of PMSM with } \\
\text { trapezoidal back } \\
\text { EMF when } \\
\text { controlling PMSM } \\
\text { with sinusoidal back } \\
\text { EMF, the average } \\
\text { torque is lower by } \\
5 \%\end{array}$ \\
\hline & & & $\begin{array}{l}\text { Iithout a } \\
\text { or position } \\
\text { sensor }\end{array}$ & $\begin{array}{l}\text { A more powerful } \\
\text { control system } \\
\text { required }\end{array}$ & $\begin{array}{l}\text { Not suitable for low- } \\
\text { speed operation. } \\
\text { There are torque } \\
\text { ripples. It is intended } \\
\text { for control of PMSM } \\
\text { with trapezoidal } \\
\text { back EMF, when } \\
\text { controlling PMSM } \\
\text { with sinusoidal back } \\
\text { EMF, the average } \\
\text { torque is lower by } \\
5 \% \text {. }\end{array}$ \\
\hline
\end{tabular}

\section{ACOUSTIC NOISE AND VIBRATION IN PMAC AND PMDC} MOTOR DRIVES

The Acoustic Noise and Vibration (ANV) is often a problem not only in the working environment, caused by production machinery in the factory to business machines in the office but also in homes from the hair-dryer to the washing machines [22-23]. Since the acoustical energy loss is insignificant, this explains why design engineers do not worry about the acoustical energy loss and noticeable noise problems. On the other hand, owing to increasing economic pressures, modem electrical machines are designed to use higher currents and flux-densities, which often result in noise problems [22]. Hence, noise control is of interest to machine designers, work engineers and safety officers, and others. Due to many concerns, it is required to reduce machinery noise. Many manufacturers, now, attempt to reduce the noise of their products at the design stage [22].

When electrical and mechanical mechanisms operate within a machine, the dynamic forces produce structural vibrations in the machine. These vibrations are transmitted through the machine and produce exterior surface vibrations and related sounds. Noise from machinery is usually complex and it is a combination of many sinusoidal components [22]. It is always important to understand the origin of the noise and magnitude of the noise before any noise-control methods are performed. The analysis of the sound from a machine provides very important information on the design and performance of the machine. Also, it provides useful information for future improvements. Acoustic noise, vibration, and quality of sound in electrical drives are an area of interest among the research community since recent years [23-27].

In rotating electrical machines noise and vibration have been classified in the following three categories, which the first one is aerodynamic noise, the second one is mechanical noise and the third one is electromagnetic noise which is shown in Fig. 8 [22].

Mechanical $A N V$ is related to the mechanical assembly, unbalanced, and geometry of the structure.

Electromagnetic $A N V$ is related to parasitic effects due to higher space and time harmonics of the magnetic field, eccentricity, phase unbalanced, slot opening, magnetic saturation, and magnetostrictive expansion of core laminations.

Aerodynamic $A N V$ with the flow of ventilating air through or over the electrical motors.

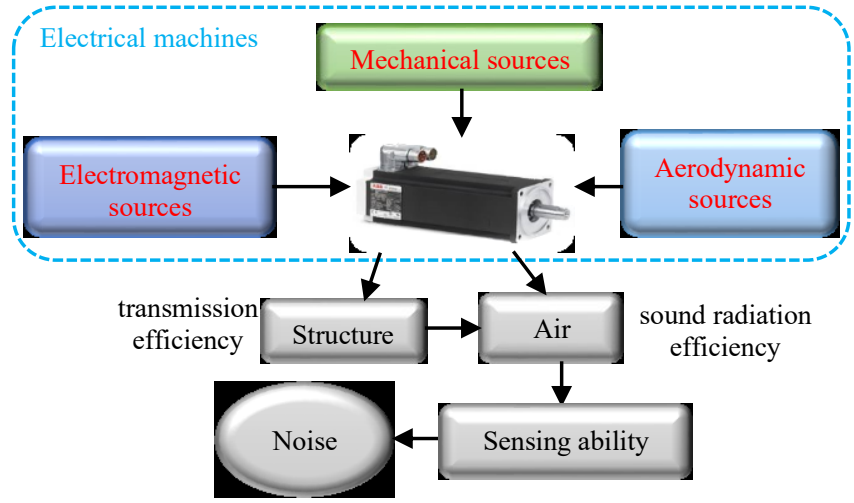

Fig. 8. Noise generation and propagation in electrical machines.

\section{A. Acoustic Noise and Vibration Reduction Techniques}

The relation between the flux density and radial forces in the airgap of the PMSM drive is defined as; the radial forces are directly proportional to the square of the flux density in the air gap. The easy and fast ways to mitigate ANV would decrease the flux density by increasing the air gap. Skewing the stator slots decreases the radial forces of PMSM drive, which results in a decreased level of acoustic noise and 
vibration [24]. Various guidelines are available for how to design stator slots and how to select the number of slots to mitigates unbalanced magnetic pull and locking between stator slots and rotor of PMSM drives, it can help reduce the ANV of PMSM drive [20-26]. Many methods are available in the literature to eliminate the space harmonics which is generated by power electronic converters [28-32].

The popular methods are Random Pulse Position (RPP), random switching operation, and a random switching frequency of power electronic semiconductor switches of three-phase voltage source inverters. The Random Pulse Width Modulation (RPWM) technique has been presented by A. M Trzynadlowski, et al. in the year 1994 [30]. The major contrast between exemplary PWM and RPWM strategy is, that the power carried by the PWM signal is no longer limited to a few leading frequencies that are normally controlled by the switching frequency and the modulated signal [31-32]. The following are the three fundamental ideas used in the current RPWM techniques:

\section{(i) Randomized Switching Frequency}

Randomization of the switching frequency has been, so far, the most widely recognized methods for RPWM. It very well may be regular or natural sampling mode. The standard testing model is described by an integer number, $N$, of exchanging spans per the pattern of the yield recurrence and a number, $N_{\mathrm{s}}$, of switching intervals used for each $60^{\circ}$ subcycle. Either $N$ or $N_{\mathrm{s}}$ can be randomly changed from cycle to cycle or from sub-cycle to sub-cycle, individually [30].

\section{(ii) Randomized Pulse Position}

In this strategy, the pulses of switching signals are randomly placed in individual switching intervals. The least complex methodology comprises of a random selection only two possible positions, namely at the beginning or at the end of the interval (lead-lag RPWM) [30].

\section{(iii) Random Switching}

In this method, the randomly produced partial numbers having uniform probability distribution are compared with the desired duty ratios. The random switching PWM strategy is straightforward since no exact planning of the switching signals is required [30].

\section{CONDITIOn Monitoring AND FAUlt Diagnosis}

Because of the huge use of electric motors, fault diagnosis and condition monitoring are an area of capital importance for the industry. Bulky electric motors are especially related due to their high costs (a single MW motor can reach a cost above \$1 million), criticality, and complex repairs [33]. An examination of large motors can indicate expenditures of several thousands of dollars, especially if it requires motor disassembly. Moreover, unpredicted faults in these machines may lead to losses in the range of millions of dollars, as reported in some applications [34], due to production downtimes and repair costs, among others.

In this regard, recent works demonstrated that the presence of stator asymmetries, rotor problems, bearing faults, cooling system defects, or coupling system problems may yield important drops in the efficiency of the machine [35], which is a consequence that reinforced the importance of proper knowledge of the health of these machines. The fact of depending on multiple and complementary informational sources enables reaching a more accurate and robust conclusion of the integral motor health. This idea is shown in Fig. 9 [33].

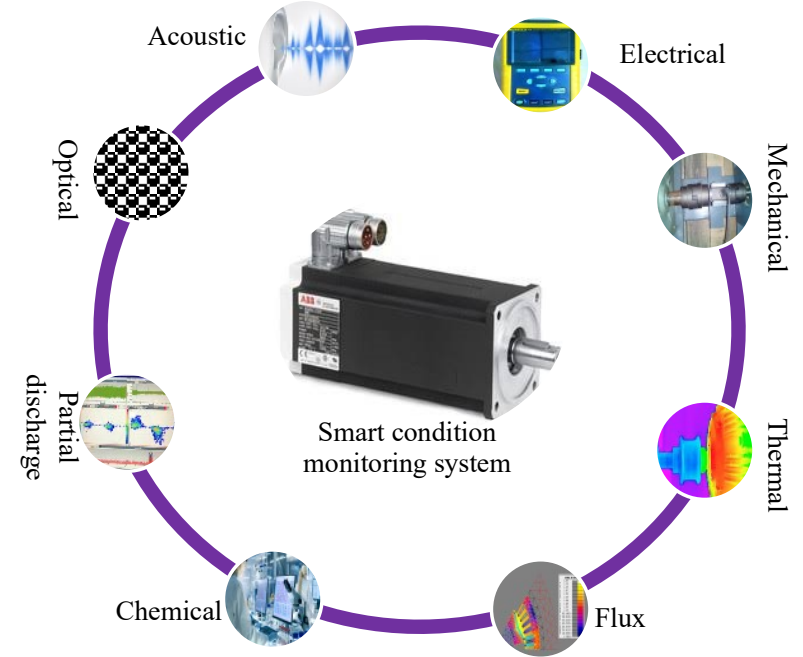

Fig. 9. The current trend in the electric motor drive condition monitoring area is based on the integration of the monitoring of different motor quantities for the development of a smart diagnostic system.

\section{RESEARCH SCOPE}

After the comprehensive review of the brushless PMAC and PMDC motor drives, now discuss the future research scope of these motor drives. Future research scopes are the following ways.

$>$ Design a high-performance power electronics control algorithm for control the speed and torque of PMs drives.

$>$ Develop less computation time taking control algorithms for sensorless operation of PMs drives.

$>$ Analysis of acoustic noise and vibration of PMs drives.

$>$ Reduction techniques for reduction of acoustic noise and vibration of PMs drives.

$>$ Faults diagnosis and condition monitoring of brushless PMs drives.

$>$ Design smart condition monitoring systems.

\section{CONCLUSIONS}

This paper has presented a state of the art on brushless Permanent Magnet Alternative Current (PMAC) and Permanent Magnet Direct Current (PMDC) motor drives. It is observed that both drives i.e. PMAC and PMDC motor are the same, but it has a minor difference in how to drive it. Based on driving the motors and the shape of the back EMF, it is identifying the types of permanent magnet drives. This paper also discussed the various control topologies for both drives. A brief overview of the research problems and solutions has been discussed. The future scope of the research on the brushless PMAC and PMDC motor drive has been presented.

\section{REFERENCES}

[1] S. K. Sul, "Control of Electric Machine Drive Systems", $1^{\text {st }}$ Edition, John Wiley \& Sons, Inc., Hoboken, New Jersey, 2011.

[2] K. T. Chau, C. C. Chan, and C. Liu, "Overview of Permanent Magnet Brushless Drive for Electric and Hybrid Electric Vehicles," in IEEE 
Transactions on Industry Electronics, vol. 55, no. 6, pp. 2246-2257, June 2008.

[3] R. Krishnan, "Permanent Magnet Synchronous and Brushless DC Motor Drives", $I^{\text {st }}$ Edition, CRC Press, Taylor \& Francis Group, FL, 2009.

[4] W. Leonhard, "Control of Electrical Drives", Springer-Verlag, 2001.

[5] D. W. Novotny and T. A. Lipo, Vector Control and Dynamics of AC Drives, Oxford University Press, New York, 1996.

[6] P. Vas, "Sensorless Vector and Direct Torque Control", Oxford University Press, New York, 2003.

[7] G. K. Dubey, "Fundamentals of Electrical Drives", $2^{\text {nd }}$ Edition, Narosa Publishing House, New Delhi, 2011.

[8] M. Chinchilla, S. Arnaltes, and J. C. Burgos, "Control of Permanent Magnet Generators Applied to Variable Speed Wind Energy Systems Connected to the Grid," in IEEE Transactions on Energy Conversion, vol. 21, no. 1, pp. 130-135, March 2006.

[9] B. K. Bose, "Modern Power Electronics and AC Drives", $4^{\text {th }}$ Edition, South Asia: Pearson Prentice-Hall, 2007.

[10] J.R. Hendershot and T. J. E. Miller, "Design of Brushless PermanentMagnet Motors", Magna Physics Publishing and Clarendon Press, Oxford, 1994

[11] Online:https://en.engineeringsolutions.ru/motorcontrol $/ \mathrm{pmsm} /$

[12] P. B. Reddy, A. M. El-Refaie, K. Huh, J. K. Tangudu, and T. M. Jahns, "Comparison of Interior and Surface PM Machines Equipped With Fractional-Slot Concentrated Windings for Hybrid Traction Applications," in IEEE Transactions on Energy Conversion, vol. 27, no. 3, pp. 593-602, Sept. 2012.

[13] C. Xia, J. Zhao, Y. Yan and T. Shi, “A Novel Direct Torque Control of Matrix Converter-Fed PMSM Drive Using Duty Cycle Control for Torque Ripple Reduction", in IEEE Transactions on Industry Electronics, vol. 61, no. 6, pp. 2700- 2713, June 2014

[14] M. Preindl and S. Bolognani, "Model Predictive Direct Torque Control with Finite Control Set for PMSM Drive Systems, Part 1: Maximum Torque per Ampere Operation", in IEEE Transactions Industry Informatics, vol. 9, no. 4, pp. 1912-1921, November 2013.

[15] G. Wang, M. Valla, and J. Solsona, "Position Sensorless Permanent Magnet Synchronous Machine Drives-A Review," in IEEE Transactions on Industry Electronics, vol. 67, no. 7, pp. 5830-5842, July 2020.

[16] C. S. Staines, G. M. Asher, and M. Sumner, "Rotor Position Estimation for Induction Machines at Zero and Low Frequency Utilizing ZeroSequence Currents," in IEEE Transactions on Industry Application, vol. 42, no. 1, pp. 105-112, January/February 2006.

[17] T. Muller, C. See, A. Ghani, A. Bati, and P. Thiemann, "Direct Flux Control - Sensorless Control Method of PMSM for all Speeds - Basics and Constraints," in Electronics Letters, vol. 53, no. 16, pp. 1110-1111, 17 August 2017.

[18] N. Forster, A. Gerlach, and R. Leidhold, "Improved Angle Estimation for PM Synchronous Machines with Non-Sinusoidal Saliency," IECON 2018 - 44 $4^{\text {th }}$ Annual Conference of the IEEE Industry Electronics Society, Washington, DC, 2018, pp. 534-540.

[19] J. L. Shi, T. H. Liu, and Y. C. Chang "Position Control of an Interior Permanent Magnet Synchronous Motor Without Using a Shaft Position Sensor" in IEEE Transactions on Industry Electronics, vol. 54, no. 4, pp. 1989-2000, August 2007.

[20] N. Forster, A. Gerlach, and R. Leidhold, "Improved Angle Estimation for PM Synchronous Machines with Non-Sinusoidal Saliency," IECON 2018 - 44 $4^{\text {th }}$ Annual Conference of the IEEE Industry Electronics Society, Washington, DC, 2018, pp. 534-540.

[21] A. K. Yadav, R. M. Pindoriya and B. S. Rajpurohit, "Design and Implementation of Rotor Position Estimation Scheme for PMSM Drive," 2020 IEEE 9th Power India International Conference (PIICON), SONEPAT, India, pp. 1-6, 2020.

[22] J. F. Gieras, C. Wang and J. C.S. Lai, "Noise of Polyphase Electrical Motors", Taylor \& Francis Group, 2006.

[23] S. Hwang, J. Eom, G. Hwang, W. Jeong, and Y. Jung, "Cogging Torque and Acoustic Noise Reduction in Permanent Magnet Motors by Teeth Pairing," in IEEE Transactions on Magnetics, vol. 36, no. 5, pp. 3144-3146, 2000.

[24] S. P. Verma, K. Williams, and R. K. Singal, "Vibrations of Long and Short Laminated Stators of Electrical Machines, Part I: Theory, Experimental Models, Procedure, and Set-Up", Sound Vibration, no. 129, pp. 1-13, 1989.
[25] ISO standard 7919-2: 2001, "Reference Standards for Vibration Monitoring and Analysis", pp. 1-10, 2001.

[26] IEEE standard 85-1980, "IEEE Test Procedure for Airborne Sound Measurements on Rotating Electric Machinery", New York, USA, pp. 1-21, Dec. 1980.

[27] J. Krotsch and B. Piepenbreier, "Radial Forces in External Rotor Permanent Magnet Synchronous Motors with Non-overlapping Windings," in IEEE Transaction Industrial Electronics, vol. 59, no. 5, pp. 2267-2276, May 2012.

[28] C. Xia, J. Zhao, Y. Yan and T. Shi, "A Novel Direct Torque Control of Matrix Converter Fed PMSM Drive using Duty Cycle Control for Torque Ripple Reduction", in IEEE Transactions on Industrial Electronics, vol. 61, no. 6, pp. 2700- 2713, Jun. 2014.

[29] M. Preindl and S. Bolognani, "Model Predictive Direct Torque Control with Finite Control Set for PMSM Drive Systems, Part 1: Maximum Torque per Ampere Operation," in IEEE Transactions on Industrial Informatics, vol. 9, no. 4, pp. 1912-1921, Nov. 2013.

[30] A. M. Trzynadlowski, F. Blaabjerg, J. K. Pedersen, R. L. Kirlin, and S. Legowski, "Random Pulse Width Modulation Techniques for Converter-fed Drive Systems-A Review," in IEEE Transactions on Industry Applications, vol. 30, no. 5, pp. 1166-1175, SeptemberOctober 1994.

[31] R. M. Pindoriya, G. Gautam and B. S. Rajpurohit, "A Novel Application of Pseudorandom Based Technique for Acoustic Noise and Vibration Reduction of PMSM Drive," in IEEE Transactions on Industry Applications, doi: 10.1109/TIA.2020.2997904.

[32] R. M. Pindoriya, B. S. Rajpurohit and R. Kumar, "A Novel Application of Harmonics Spread Spectrum Technique for Acoustic Noise and Vibration Reduction of PMSM Drive," in IEEE Access, vol. 8, pp. 103273-103284, 2020.

[33] J. A. Daviu, "Electrical Monitoring under Transient Conditions: A New Paradigm in Electric Motors Predictive Maintenance", Applied Science, 10, 6137, 2020.

[34] J. A. Daviu, V. F. Roig, S. Park, Y. Park, H. Choi, and J. Park, "Electrical Monitoring of Damper Bar Condition in Salient-Pole Synchronous Motors Without Motor Disassembly", IEEE Transcations on Industry Applications, 56, 1423-1431, 2020.

[35] M. Garcia, P. Panagiotou, J. A. Daviu, K. N. Gyftakis, "Efficiency Assessment of Induction Motors Operating Under Di erent Faulty Conditions", IEEE Transcations on Industry Electronics, 66, 8072-8081, 2019. 